\title{
Füstös Mónika
}

\section{A feljelentési hajlandóság és a rendőrségbe vetett bizalom összefüggései. Szisztematikus szakirodalmi áttekintés a Web of Science alapján}

\author{
Trust in the police and willingness to report crimes. \\ A systematic literature review based on Web of Science
}

\begin{abstract}
Absztrakt
A rendőrségbe vetett bizalom és a feljelentési hajlandóság közötti kapcsolatot a szakirodalom sokáig evidensnek vette, annak ellenére, hogy ezt kevés empirikus kutatás támasztotta alá. Az elmúlt néhány évben azonban a kutatók figyelmét felkeltette a téma, világszerte egyre több kutatásról publikálnak eredményeket. Ez a tanulmány az eddig angol nyelven megjelent kutatások eredményeit összegzi, és tudománymetriai szempontból is megvizsgálja azokat. A Web of Science keresőjét használva, összesen 41 olyan angol nyelvü, 1975 és 2020 között megjelent kutatást találtam, amely a két fogalom közötti kapcsolatot vizsgálja. Ezeket elemezve kiderült, hogy az elmúlt öt évben megugrott a téma iránti érdeklődés, elsősorban a kriminológia, másrészt a jog és társadalomtudományok terén. Kiderült az is, hogy a gazdaságilag fejlett országokban publikálnak a leggyakrabban, ezen belül is az angolszász országok vannak az élbolyban. Az is láthatóvá vált, hogy az eredmények jelentős szórást mutatnak, igaz jóval több az olyan kutatás, amely a két fogalom közötti kapcsolatot igazolja, s szép számmal akad olyan is, amely ennek éppen ellentmond. A kutatásból úgy tünik a megosztó eredmények sem a gazdasági fejlettséggel, sem azzal nem mutatnak összefüggést, hogy a tanulmány mikor jelent meg. Annak érdekében, hogy a rendőrségbe vetett bizalom és a feljelentési hajlandóság közötti összefüggéseket megérthessük, az összefüggést kvalitatív módszerekkel, illetve az erre a célra létrehozott kérdőívekkel is szükséges lenne kutatni.
\end{abstract}


Kulcsszavak: rendőrség, bizalom, feljelentési hajlandóság, kutatás, tudománymetria

\begin{abstract}
For many years criminology has assumed that the more victims trust the police, the more they will be willing to report crimes. Yet, the relationship between trust in the police and victims' willingness to report has rarely been considered empirically. In the last few years, however, the topic has been attracting more and more attention worldwide. This study reviews the articles published on this topic in English so far and examines them from the perspective of scientific metrics, including the numerical distribution of the correlation. Using the search function of Web of Science, a total of 41 articles were found published between 1975 and 2020 that studied the relationship between the two concepts. Analysing these, it has emerged that research interest in the subject has increased over the past five years, primarily in criminology, but also in the fields of law and social sciences. The results also show that most researches comes from economically more developed regions, mainly Anglo-Saxon areas. The main finding of this article is that the research results are inconsistent. Although most researches confirms the relationship between trust in the police and willingness to report crimes, there are many studies that contradict this. Furthermore, the controversial results do not seem to correlate with the level of economic development nor with the date when the research was published. Therefore, the relationship between trust in the police and the willingness to report crimes should also be researched using qualitative methods in order to gain a deeper understanding of this complex topic, and questionnaires should be designed specifically for this purpose.
\end{abstract}

Keywords: police, trust, willingness to report, research, science metrics

\title{
Bevezetés
}

A kriminológusokat régóta foglalkoztatja, hogy miért tesznek egyes áldozatok feljelentést, míg mások úgy döntenek, hogy nem értesítik a rendőrséget, amikor büncselekményt követnek el ellenük (Block, 1974; Skogan, 1976; Skogan, 1984). Ez a tudás nemcsak elméleti szempontból fontos, hanem gyakorlati, a rendőrség müködését meghatározó szempontok miatt is. Elméleti szinten fontos, hiszen addig nem ismerjük a bünözés teljes valóságát, amíg a látenciában maradt esetekröl nincsenek ismereteink, gyakorlati szinten pedig fontos a rendőrség mindennapos müködése szempontjából megismerni azokat az okokat, amelyek a feljelentés melletti döntésben szerepet játszanak, hiszen a rendőrség munkáját ehhez lehet 
igazítani. A látenciakutatásokból néhány fontos okot egyértelműen sikerült azonosítani, ilyen például a vagyon elleni büncselekmények esetében a biztosítás, mint erős ösztönző, de erős szignifikáns összefüggést mutat például a büncselekmény áldozat által érzékelt komolysága is; minél súlyosabbnak érzékeli az ellene elkövetett büncselekményt, annál valószínübb, hogy feljelentést tesz (Skogan, 1984). A kriminológiai szakirodalom hosszú ideig evidensnek vette a rendőrségbe vetett bizalom és a feljelentési hajlandóság közötti kapcsolatot is (Kääriäinen \& Sirén, 2011), korábban azonban csak szórványosan kutatták az összefüggést empirikus módszerekkel (Fishman, 1979; Bennett \& Wiegand, 1994; Sunshine \& Tyler, 2003; Goudriaan, Lynch \& Nieuwbeerta, 2004; Goudriaan, Wittebrood \& Nieuwbeerta, 2006; Davis \& Hendricks, 2007; Tyler \& Fagan, 2008; Tankebe, 2009; Slocum, Taylor, Brick \& Esbensen, 2010; Tyler, Schulhofer \& Huq, 2010). Az elmúlt öt-tíz évben azonban egyre több kutatás jelent meg a témát vizsgálva (Kääriäinen \& Sirén, 2011; Murphy \& Cherney, 2011; Kochel, Parks \& Mastrofski, 2013; Semukhina, 2014; Murphy \& Barkworth, 2014; Sargeant, Murphy \& Cherney, 2014; Tsushima \& Hamai, 2015; Kruger et al., 2016; Tyler, 2001; Tankebe, 2016; Van Damme, 2016; Karakus, 2017; Khondaker, Wu \& Lambert, 2017; Murphy et al., 2017; Slocum, 2018; Wiedlitzka, Mazerolle, Fay-Ramirez \& Miles-Johnson, 2018; Boateng, 2018; Murphy \& Mazerolle, 2018; Griffiths, 2018; Elntib, Nass, Ioannou, Ryan \& Christiansen, 2018; Özaş̧̧1ar, Narli, N \& Öztürk, 2018; Sun, Li, Wu \& Hu, 2018; Kwak, Dierenfeldt \& McNeeley, 2019; Rengifo, Slocum \& Chillar, 2019; Tankebe, 2019; Murphy, Cherney \& Teston, 2019; Tankebe, 2019; Murphy, Madon \& Cherney, 2020; Pósch, Jackson, Bradford \& Macqueen, 2020; Li, Sun, Wu \& Liu, 2020; Lee \& Cho, 2020a, 2020b; Jackson et al., 2020). Ezen írás célja, hogy a témában született angol nyelvü kutatási eredményeket szisztematikusan feldolgozza, (1) rávilágítva, hogy kik, mikor és hol vizsgálták a feljelentési hajlandóság és a rendőrségbe vetett bizalom kérdését; és (2) megvizsgálva milyen eredményre jutottak ezek a kutatások. A cikk tehát a tématerület statisztikai elemzését mutatja be.

\section{Módszertan}

Annak érdekében, hogy a kutatási eredmények feldolgozottsága szisztematikus legyen, szigorú módszertant követve gyüjtöttem össze a vizsgált cikkeket. Ehhez a Web of Sciences (WoS) keresőjét alkalmaztam. A WoS egy elöfizetésen alapuló weboldal, amely hozzáférést biztosít több olyan adatbázishoz, amelyek különféle tudományterületen kínálnak tudományos igényü kutatási cikkeket. Az oldal kiválóan alkalmas a hivatkozások és publikációk keresésére és mérésére. 
Az oldal hasonlóan müködik, mint a Google Scholar, annál azonban rendszerezettebb (például több szürési lehetőség) keresést tesz lehetővé, továbbá fontos szempont, hogy adatbázisa csak referált múveket tartalmaz. A szakirodalmi áttekintéshez 1975 és 2020 között megjelent angol nyelvü tanulmányok között kerestem, úgy, hogy a témát jelöltem meg keresési körnek. Ez azt jelenti, hogy a keresőmotor nem csupán az egyes cikkek címeiben, hanem egész tartalmában kereste az általam megadott kereső szavakat, kifejezéseket.

A kutatás során kvantitatív módszerekkel vizsgáltam az alábbi változókat: megjelenés éve, kutatás helyszíne, legtöbbet publikáló szerzők, megjelentető folyóiratok, tudományterület. Ezen adatok birtokában általános képet kaphatunk a két fogalom kapcsolatát kutató alapvető tendenciákról és a tudománymetriai helyzetéröl is. A kutatás során a fő vizsgálati szempont továbbá az volt, hogy meghatározzam, hogy a feljelentési hajlandóság és a rendőrségbe vetett bizalom között milyen jellegủ összefüggés van, vagyis a kutatási cikkeket tartalmilag is megvizsgáltam, majd a korrelációk számszerinti megoszlását bemutatom.

\section{A keresöszavak}

A módszertani keretek meghatározása során az egyik fontos lépés a releváns keresőszavak és kifejezések meghatározása volt. Nem volt ugyanis elégséges a legevidensebb kifejezések használata, mert például a rendőrségbe vetett bizalom (trust in police) és a feljelentési hajlandóság (willingness to report) kifejezésekre együtt keresve (AND paranccsal) a WoS keresője mindössze két találatot (Murphy \& Mazerolle, 2018; Sulkowski, 2011) ad ki. A leggyakrabban használt szinonimák, kifejezések, fogalmak az angol nyelvü szakirodalomban a rendőrségbe vetett bizalomra a következők: trust in police; confidence in police; victims' perceptions of police performance; procedural justice; procedural fairness; instrumental justice; instrumental fairness; effectiveness; victim satisfaction; attitudes toward the police; attitude towards law enforcement. A leggyakoribb kifejezések a feljelentési hajlandóság kifejezésre vagy ahelyett használt rokon fogalmak a következök: unreported crimes; crime reporting; notification; willingness to report; cooperation with the police.

Ezek a kifejezések összesen 55 féle keresési kombinációt jelentenek az AND parancs használatával, egy-egy keresés tehát így nézett ki: „trust in police” AND ,unreported crimes”. Az összes ilyen keresési kombinációt figyelembe véve a keresőszavak közül néhány (procedural justice, effectiveness, cooperation with the police) nagyon sikeresnek bizonyult, vagyis sok találatot sikerült a használatukkal elérni, míg néhány teljesen feleslegesnek (unreported crimes, instrumental justice; instrumental fairness, attitude towards law enforcement), mivel semmilyen kombinációban sem adtak egyetlen találatot sem. 


\section{Kategorizálás}

Az összes kombináció szisztematikus feldolgozása után több, mint száz kutatási cikket adott ki a WoS keresője. A gyüjtés 2020 decemberében zárult le, így a később, a témában megjelenő cikkek már nem kerültek be az elemzésbe. Voltak olyan cikkek, amelyek témájuk alapján azonnal kiestek, vagyis a kutatás szempontjából nem releváns kategóriába kerültek, voltak azonban olyanok is, amelyek látszólag érintették a témákat, ugyanakkor nem a két fogalom kapcsolatát vizsgálták, sőt néhány olyan cikket is kiadott a kereső, amely érintette a két fogalom közötti kapcsolat témáját, de nem saját kutatáson alapult a kapcsolat vizsgálata, hanem másik kutatásra hivatkozott. Miután ezen szempontok alapján kiválogattam a kutatás szempontjából releváns és nem releváns cikkeket, 41 tanulmány került az elemzendő cikkek kategóriába, amelyeket egyrészt a WoS által rendelkezésre álló adatok, másrészt saját adatbázis készítésével elemeztem. Ez az adatbázis az összes elemzett cikk elolvasása után készült, és összegezte a szerzők nevét, a publikálás évét, az adatfelvétel helyszínét, az adott cikk fogalomhasználatát, a használt módszereket és az eredményeket.

\section{Fogalmak}

A vizsgált kutatási cikkekben a szerzők különböző fogalmakat használnak. Az együttmüködési hajlandóság és a feljelentési hajlandóság között alapvetően az a különbség, hogy előbbi tágabb fogalom, ide sorolják azt is, ha valaki telefonon jelent egy büncselekményt, információt ad a rendőrségnek, vagy ha a rendőrség megkéri rá együttmüködik, segíti a rendörség munkáját (Sargeant et al., 2014). A kutatók a fogalmakat vegyesen használják: az együttműködési hajlandóság fogalmát a vizsgált kutatások többet használták, mint a feljelentési hajlandóságot. 
1. számú ábra: A rokon fogalmak használatának gyakorisága a vizsgált kutatásokban I.

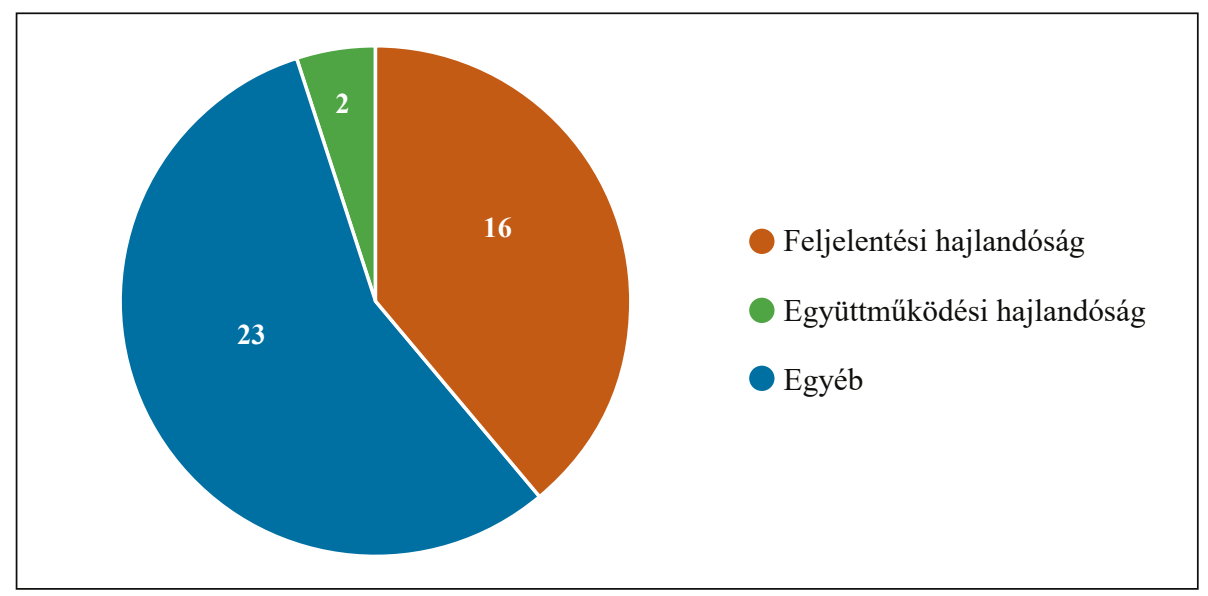

Forrás: A szerző saját szerkesztése.

Ha bízunk valakiben, az azt jelenti, hogy hiszünk abban, hogy jóhiszemüen jár el velünk szemben, és hogy kompetens abban, amit rábízunk (Hardin, 2006). Hardin meghatározása azért fontos, mert láthatóvá válik, hogy a bizalom két dimenziót tartalmaz: a jóhiszemüséget (procedurális vagy eljárásalapú bizalom) és a kompetenciát (instrumentális vagy eredményalapú bizalom). A rendőrségbe vetett bizalom tehát jelzi a rendőrség hatékonyságát, és a testületről meglévő tapasztalatai, információi alapján feltételezi, hogy mennyire járnának el méltányosan (procedurális igazságosság) vele szemben. A rendőrség legitimitása a hatékonyság és procedurális méltányosság mellett magába foglalja a törvényességet/jogszerüséget (lawfulness) és az elosztás méltányosságát (distributive fairness) is (Tankebe, Reising \& Wang, 2016). A Bottoms-Tankebe legitimációs modellben a szerzők törvényszerüség alatt azt értik, hogy a rendfenntartás a jogállamiság és törvényesség keretei között zajlik, a rendőrség pedig a jog végrehajtója és nem a törvények alkotója. Az elosztási méltányosság a modell szerint azt tükrözi, hogy a rendőri erőforrások elosztása igazságos-e a különböző csoportok és egyének között. A modellben megkülönböztetnek konkrét és szimbolikus erőforrásokat. Ebben a kontextusban a konkrét erőforrások alatt a rendőri állomány, bírságok, bírósági költségek eloszlását érthetjük, míg a szimbolikus erőforrások alatt a tiszteletet, az udvariasságot és a méltóságot. 
2. számú ábra: A rokon fogalmak használatának gyakorisága a vizsgált kutatásokban II.

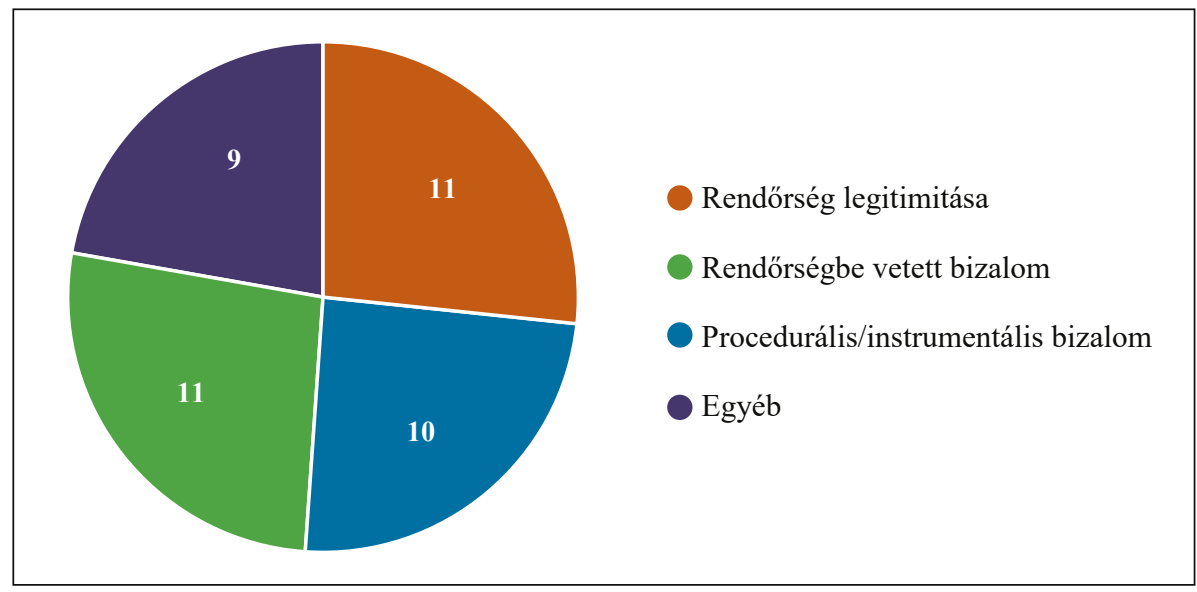

Forrás: A szerző saját szerkesztése.

A legitimitást kilenc, a bizalmat szintén kilenc, annak egy vagy mindkét összetevőjét (hatékonyság; procedurális igazságosság) szintén kilenc esetben vizsgálták, a többi kutatási cikk rendőrségről alkotott képet vagy rendőrség iránti attitüdöt vizsgál, amely a bizalommal rokon fogalmak, ezért kerültek be a kutatás szempontjából releváns cikkek közé.

\section{Eredmények}

A kutatás három területen szolgál hasznos információkkal: egyfelől kirajzolódnak olyan mintázatok, amelyből a kutatási téma tudományos életben elfoglalt helyére következtethetünk, másrészt láthatóvá válik, hogy a téma mikor és hol kapott figyelmet, harmadszor pedig rálátást kapunk a rendőrségbe vetett bizalom és a feljelentési hajlandóság összefüggéseinek kutatási eredményeire. Ezeket összevetve az időbeli és regionális eloszlással arra is választ kaphatunk, hogy az egyes változók befolyásolják-e a korrelációról megállapított eredményt.

\section{Tudománymetriai tanulságok}

Először a kutatás tudománymetria szempontjából releváns megfigyeléseit tárgyalom és szemléltetem. 
A WoS tudományterületekhez rendeli az egyes cikkeket. Ez alapján az rajzolódik ki, hogy a témával elsősorban a kriminológia területén foglalkoznak. Jelentős még a jog, a szociológia és pszichológia az érintett tudományterületek közül.

3. számú ábra: $A$ WoS által létre hozott tudományterületi eloszlás vizualizációja

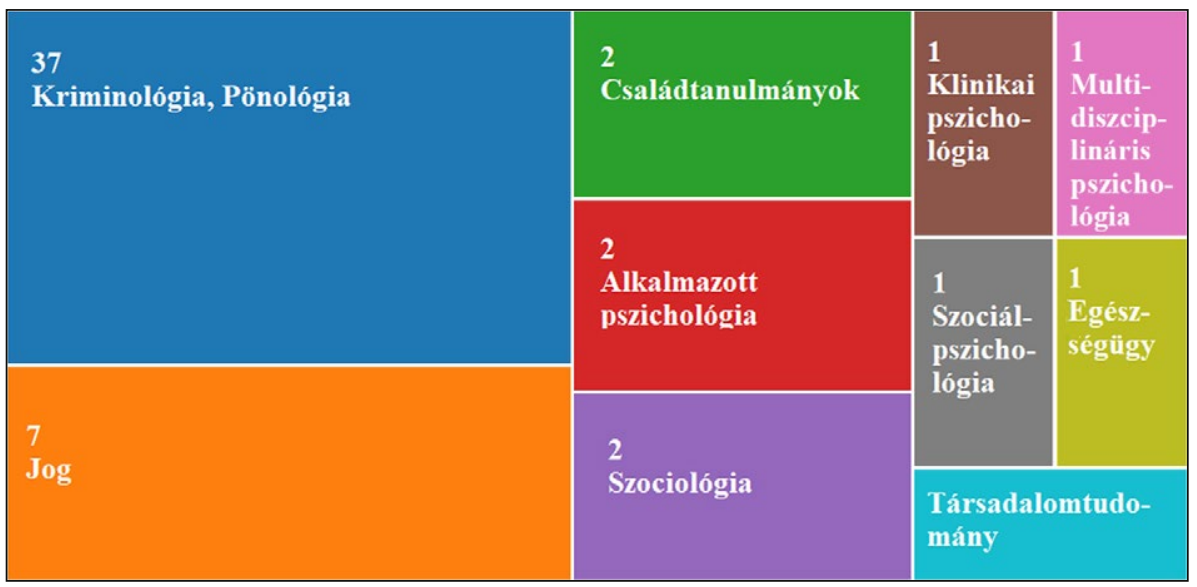

Forrás: A szerző saját szerkesztése a WoS tudományterületi felosztása alapján.

A folyóiratok vizsgálatakor is egyértelmủvé válik, hogy a rendőrségbe vetett bizalom és a feljelentési hajlandóság kapcsolatának vizsgálata elsősorban a kriminológiai szaklapok érdeklődési körébe tartozik. Emellett a jogi és rendészeti érdekeltségü folyóiratok publikálnak akár többször is erről a témáról.

1. számú táblázat: A legalább két cikket közlö folyóiratok

\begin{tabular}{|l|c|}
\hline \multicolumn{1}{|c|}{ Folyóirat címe } & Publikációk száma \\
\hline Justice Quarterly & 4 \\
\hline Australian \& New Zealand Journal of Criminology & 3 \\
\hline European Journal of Criminology & 3 \\
\hline Law and Society Review & 3 \\
\hline Criminology & 3 \\
\hline The British Journal of Criminology & 3 \\
\hline Journal of Quantitative Criminology & 2 \\
\hline Policing and Society & 2 \\
\hline
\end{tabular}

Forrás: A szerző saját szerkesztése. 
A korrelációt kutató szerzők közül az Ausztráliában kutató Murphy publikálta a legtöbb tanulmányt, ő gyakran Cherney-vel, vagyis a második legtöbbet publikáló szerzővel közösen jegyzi cikkeit. Tyler, aki a rendőrségbe vetett bizalom téma elismert és sokat hivatkozott szerzője, a korreláció kutatására is nagy figyelmet fordított. Egy nigériai kutatás kivételével Tankebe Ghánában végzett munkásságának köszönhető az, hogy az összefüggés kutatása Afrikában is megvalósul, ő gyakran összehasonlította Ghánában gyüjtött adatait más országok adataival. Három-három cikket publikált továbbá Slocum és Wu. További tíz olyan szerző (Goudriaan, Nieuwbeerta, Mazerolle, Sun, Lee, Jackson, Cho, Bradford, Madon, Pósch) szerepel az adatbázisban, akik két tanulmányt jelentettek meg.

2. számú táblázat: A legalább három cikket publikáló szerzők

\begin{tabular}{|l|c|}
\hline \multicolumn{1}{|c|}{ Szerzö } & Publikációk száma \\
\hline Murphy & 7 \\
\hline Cherney & 5 \\
\hline Tyler & 4 \\
\hline Tankebe & 4 \\
\hline Slocum & 3 \\
\hline Wu & 3 \\
\hline
\end{tabular}

Forrás: A szerző saját szerkesztése.

\section{Idézettség}

A 41 tanulmányt a WoS adatbázisa szerint összesen 2071 cikk idézte, összesen 3408-szor, önhivatkozások nélkül az idéző cikkek száma 2037, összesen 3253 szor. Ez azt mutatja, hogy a relatíve kevés empirikus kutatás ellenére a téma iránt jelentős az érdeklődés. Ezt támasztja alá az is, hogy egy cikk átlagos idézettsége 81,14. A gyüjtemény Hirsch-indexe 18, vagyis összesen 18 darab olyan cikk van az elemzettek között, amelyre legalább 18 hivatkozás érkezett.

A rendőrségbe vetett bizalom szakirodalmának egyik legjelentősebb és legtöbbet hivatkozott szerzője Tyler. A 3. számú táblázatból is jól látható, hogy az ő tanulmányai jelentős idézettséget kapnak. Tyler mellett, a fent említett, a témában többször publikáló szerzők közül többen (Tankebe, Murphy, Cherney) jelentős idézettséget is elértek. 
3. számú táblázat: A száz feletti idézettséget elérö cikkek szerzői

\begin{tabular}{|l|c|}
\hline \multicolumn{1}{|c|}{ Szerzők } & Legtöbbet idézett cikkre érkező idézetek száma \\
\hline Sunshine és Tyler & 1228 \\
\hline Tyler & 305 \\
\hline Tankebe & 229 \\
\hline Tyler, Schulhofer és Huq & 173 \\
\hline Goudriaan, Wittebrood és Nieuwbeerta & 132 \\
\hline Murphy és Cherney & 119 \\
\hline Kochel, Parks, Mastrofski & 108 \\
\hline
\end{tabular}

Forrás: A szerző saját szerkesztése.

A 4. számú ábrán az idézettség éves eloszlása látszik. Az ábra jól mutatja, hogy a téma iránti érdeklődés évről évre nő (a 2021-es hivatkozások egyelöre csak az első negyedév eredményeit mutatja).

4. számú ábra: Idézettség évek szerint

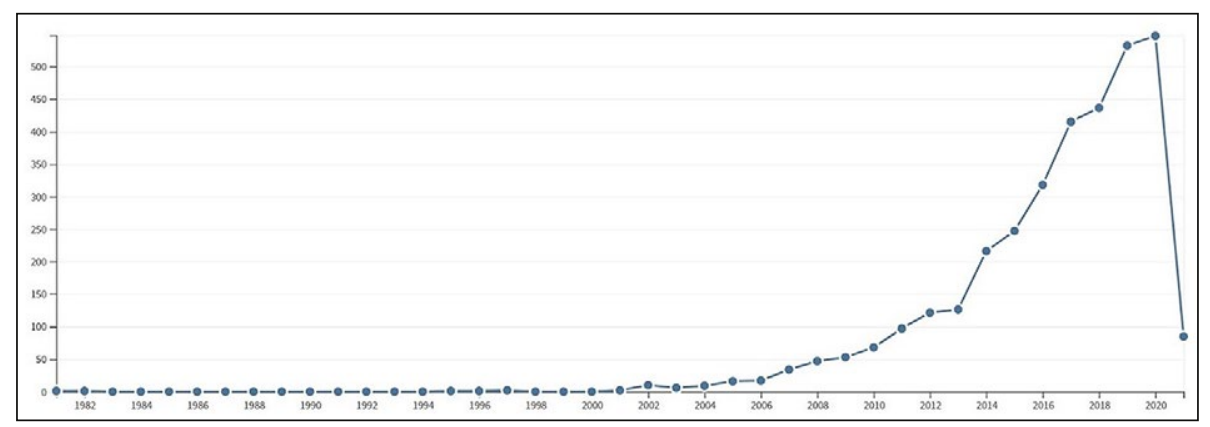

Forrás: WoS.

A következő fejezetben látható lesz, hogy maguk a megjelent publikációk száma is évröl évre növekszik. Ez természetesen hatással van az idézettség növekedésére is, ugyanakkor jól példázza a téma iránti érdeklődés növekedését is.

\section{Általános tendenciák a kutatási területen}

A rendőrségbe vetett bizalom és a feljelentési hajlandóság kapcsolatáról a 2000es évekig alig születtek empirikus kutatások. Az 5. számú ábrán látszik, hogy 
2003 után már majdnem minden évben publikáltak a témában, a téma iránti érdeklődés azonban az elmúlt öt évben ugrott meg jelentősen. Az ábrán látható trendvonal egyértelmúen rávilágít arra, hogy a téma iránti tudományos érdeklödés egyre intenzívebb.

\section{5. számú ábra: A publikációk száma megjelenési év szerint}

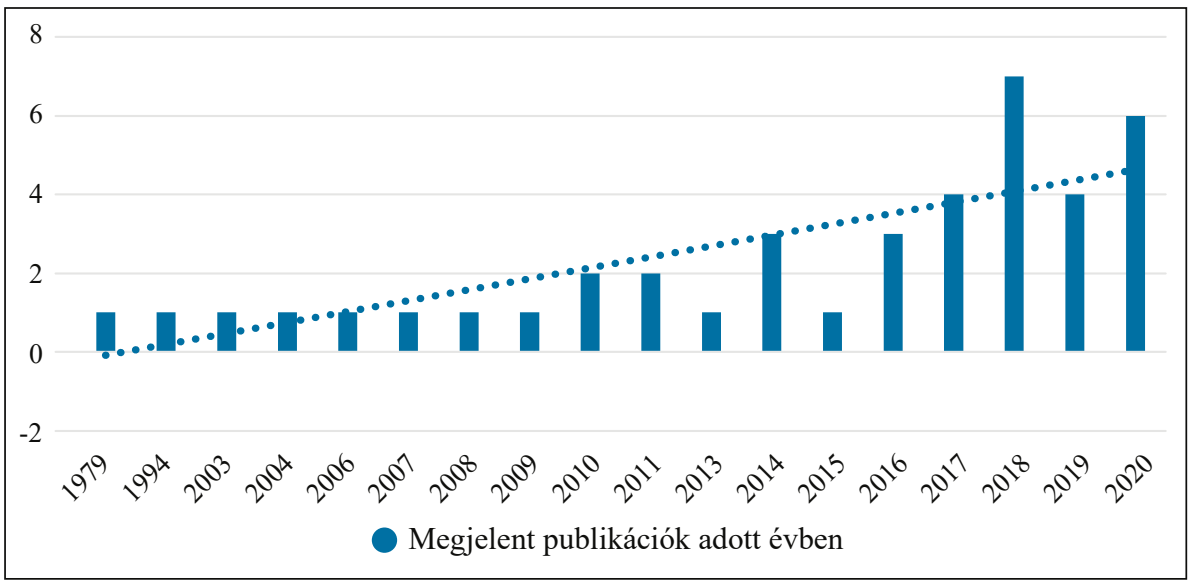

Forrás: A szerző saját szerkesztése.

A kutatás során az is láthatóvá vált, hogy mely kontinenseken és mely régiókban (fejlett/fejlődő ${ }^{1}$ ) zajlanak kutatások a két jelenség kapcsolatáról. Észak-Amerikában a legintenzívebb az érdeklődés a téma iránt. Ázsiában elsősorban a Távol-Keleten (Japán, Kína, Dél-Korea) kutatják a korrelációt. Európában a kutatások felét angolszász országokban (Anglia, Skócia) végezték, a többi kutatás pedig a Benelux államok területén zajlott. Ausztráliában szintén jelentős érdeklődés tapasztalható a téma iránt, ugyanakkor a legtöbb kutatást ugyanazon szerzők (Murphy, Cherney) publikálják. Hasonló a helyzet Afrikában, ahol az öt kutatásból négyet Tankebe publikált, így valójában elsősorban Ghánáról állnak rendelkezésre adatok. Közép- és Dél-Amerikában csak szórványosan készültek ebben a témában kutatások. A nemzetközi kutatásokban az ENSZ által végzett International Crime Victim Survey adatait vizsgálták a kutatók.

1 Az egyes országokban végzett kutatásokat fejlett és fejlődő kategóriákba soroltam. A fejlődő országok között szerepel: Ghána, Nigéria, Trinidad és Tobago, Belize; a fejlettek között: USA, Ausztrália, Skócia, Anglia, Belgium, Hollandia, Finnország, Oroszország, Törökország, Izrael, Kína, Japán, Dél-Korea. 
4. számú táblázat: A kutatások megoszlása földrészenként (a vizsgált cikkek közül kettő olyan összehasonlitó elemzést végez, amelyben az adatokat más földrészen vették fel)

\begin{tabular}{|l|c|}
\hline \multicolumn{1}{|c|}{ Földrész } & Kutatások száma \\
\hline Észak-Amerika & 10 \\
\hline Ázsia & 9 \\
\hline Európa & 7 \\
\hline Ausztrália & 8 \\
\hline Afrika & 5 \\
\hline Közép- és Dél-Amerika & 2 \\
\hline Nemzetközi & 2 \\
\hline
\end{tabular}

Forrás: A szerző saját készítése.

\section{A korreláció számszerü megoszlása}

A kutatásokat összefoglalva az látszik, hogy azok az eredmények erős túlsúlyban vannak, amelyek a fogalmak közötti pozitív kapcsolatot bizonyítják. Öszszesen 24 kutatás jutott erre az eredményre és további hat olyan kutatás volt, amely részben igazolta az összefüggést [vagy a hatékonyság és a procedurális igazságosság okozott eltérést vagy összehasonlító elemzések során egyes csoportok (többségi, kisebbségi) között volt eltérés, és volt olyan kutatás is, amely több büncselekménytípust hasonlított össze és ezek között volt eltérés]. Ezzel szemben 11 olyan kutatás került be a mintába, amelyek azt igazolják, hogy a két fogalom között nincs összefüggés vagy az összefüggés nem szignifikáns. További négy olyan kutatás is született, amelyekben a nem szignifikáns kapcsolat csupán részeredmény. Ezenfelül két olyan kutatás is van a mintában, amelyek részeredményként ugyan, de arra a következtetésre jutottak, hogy a két fogalom között negatív kapcsolat áll fenn, vagyis minél jobban bízik az egyén a rendőrségben, annál kisebb a valószínüsége annak, hogy feljelentést tesz. A 41 kutatási cikkből tehát 24 adott tisztán pozitív, 11 tisztán negatív, további hat kutatás pedig vegyes eredményt. Ez a két részeredmény bár meglepő a többi eredmény tükrében, és a józan logikát figyelembe véve sem releváns, így levonhatjuk azt a konklúziót, hogy nem valószínü, hogy a két fogalom között negatív a kapcsolat, valószínüleg valamilyen módszertani oka lehet az eltérésnek.

2 Az International Crime Victim Survey adatbázis alapján készült kutatások. A kérdőíveket hat hullámban, összesen 80 országban vették fel. 
6. számú ábra: A kutatási eredmények százalékos megoszlása

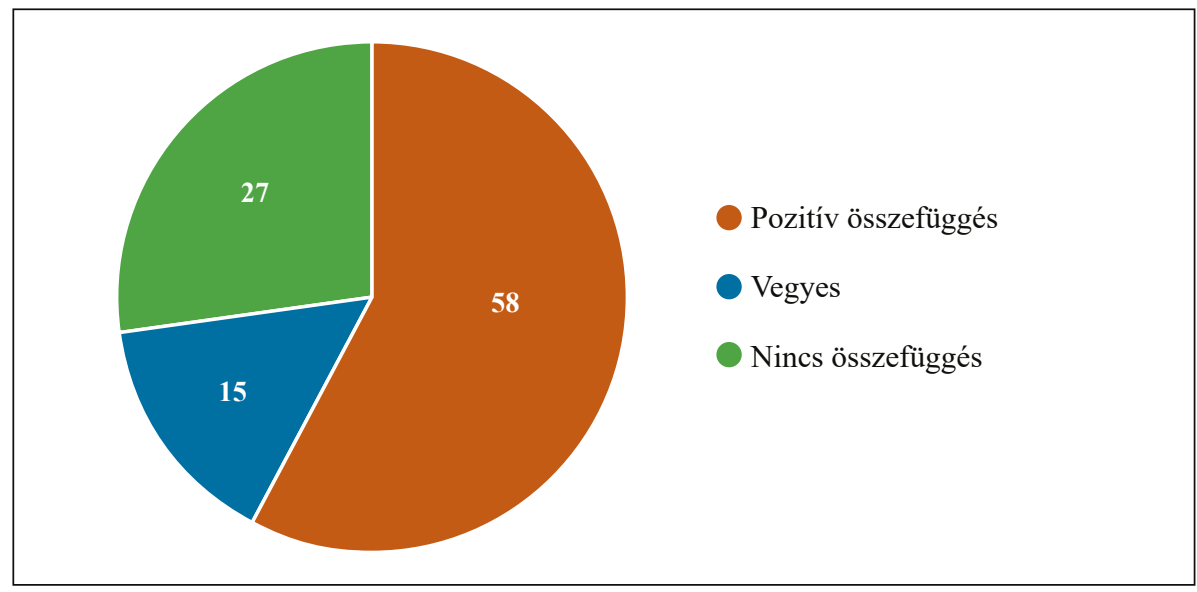

Forrás: A szerző saját szerkesztése.

Ugyanakkor az eredmények tükrében relevánsnak tünik a kérdés, hogy van-e egyáltalán kapcsolat a rendőrségbe vetett bizalom és a feljelentési hajlandóság között. A mintában szereplö kutatások több, mint duplája (24) bizonyítja a kapcsolatot, ami jelentős meggyőző erővel bír ugyan, de az a 11 kutatás, amely nem talált szignifikáns kapcsolatot, sem hagyható figyelmen kívül. Az eltérő eredmények egyfelől további kutatások szükségességét mutatják, másfelől érdemes lenne meglévő kutatásokat górcső alá venni és megtalálni az eltérések okát. Azonban az elemzett 41 cikk részletes módszertani felülvizsgálata túlmutat ennek a kutatásnak a keretein.

\section{Összefüggés időben és térben}

A rendőrségbe vetett bizalom és a feljelentési hajlandóság kutatásának kezdeti éveiben nem látható egyértelmủ trend abban a tekintetben, hogy a kutatások milyen eredményre jutnak: van összefüggés a fogalmak között, nincs összefüggés vagy vegyes az eredmény. Utóbbi alatt azt értem, hogy egyes kutatások külön vizsgálják például a procedurális és az instrumentális bizalmat, vagy öszszehasonlítják a többségi és a kisebbségi társadalmat, esetleg büncselekménytípusokra bontva vizsgálódnak és azokat hasonlítják össze. Azok a kutatások, amelyek során az egyik dimenzió összefüggést mutat, a másik nem, a vegyes kategóriába kerültek. A téma tehát az utóbbi öt évben került igazán a kutatók érdeklődési körébe, és a 7. számú ábrán jól látható, ezzel párhuzamosan egyre 
több tisztán pozitív összefüggést mutató kutatás jelent meg. Mivel feltételezhető, hogy a később publikált cikkek szerzői ismerik a korábbi szakirodalmat, így az évek során a kutatás módszertanáról is feltételezhető, hogy fejlődött, így vélhetően egyre pontosabb ismereteket szerezhetünk a két fogalom összefüggéséről.

7. számú ábra: A kutatási eredmények éves bontásban

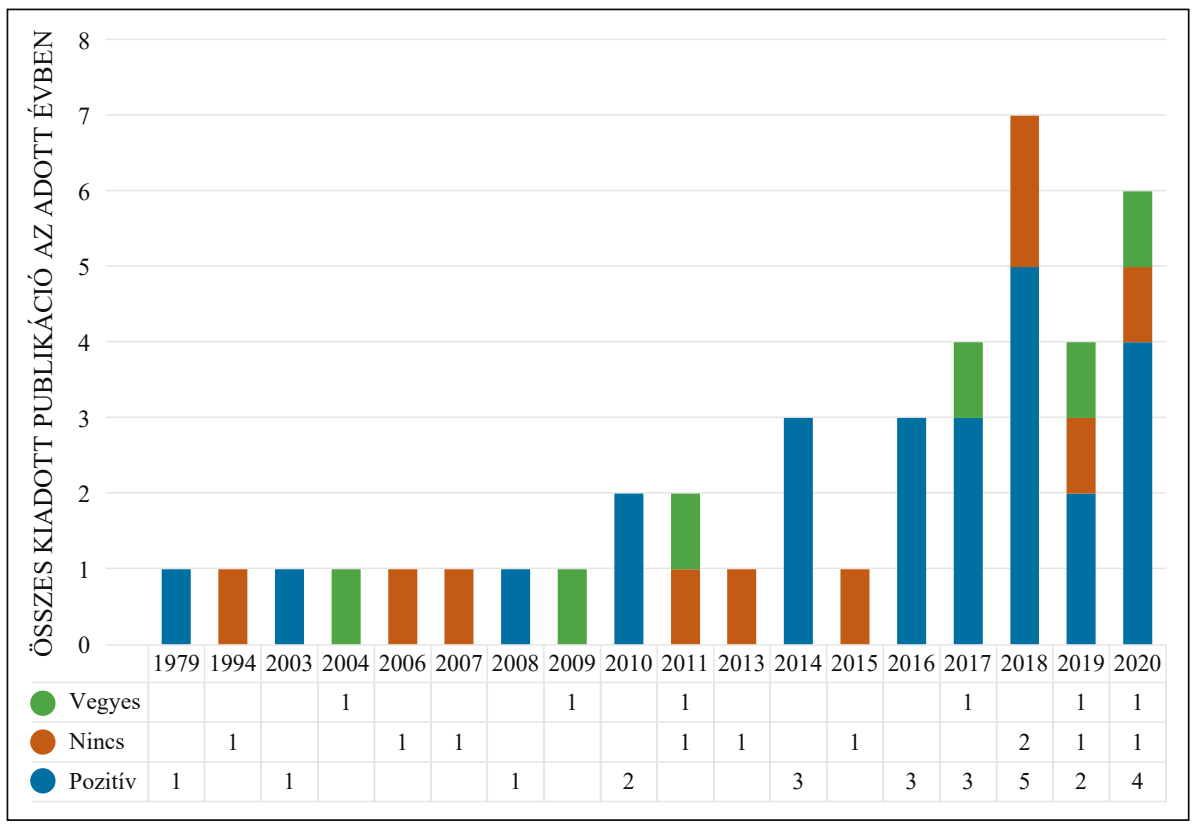

Forrás: A szerző saját szerkesztése.

A kutatás során végeztem regionális vizsgálatot is. Ebből kiderült, hogy mely kontinenseken kap jelentős figyelmet a kutatási téma. Legerősebben az angolszász területeken figyelhető meg a téma iránti érdeklődés. Kiderült továbbá, hogy a fejlett országokban sokkal intenzívebben foglalkoznak a témával, mint a fejlődő országokban. Felmerült a kérdés, hogy ennek (fejlett/fejlődő) van-e relevanciája az eredmények tekintetében. 
8. számú ábra: A belső körön ábrázolt fejlődő országokban és a külső körön ábrázolt fejlett országokban megjelent kutatási eredmények százalékos bontásban

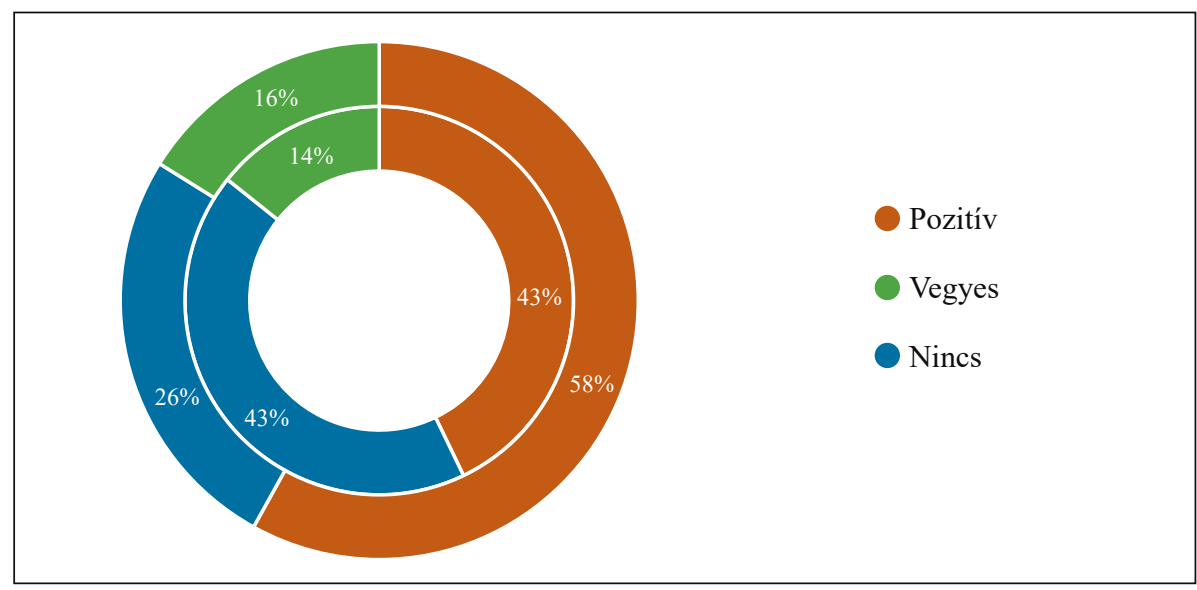

Forrás: A szerző saját szerkesztése.

A fejlett és fejlődő országok kutatási eredményeit összehasonlítva azt látjuk, hogy jelentősebb eltérés azoknál a kutatásoknál fedezhető fel, ahol a kutatók nem találtak kapcsolatot a két fogalom között. Ebböl azonban messzemenő következtetést nem érdemes és nem is lehetséges levonni az alacsony elemszámok miatt. A mintában összesen hét fejlődő országban készült kutatás van, amely nem elégséges ahhoz, hogy egyértelmü tendenciákat állapíthassunk meg.

\section{Konklúzió}

Fentebb többször felvetetettem a módszertani szupervízió szükségességét, a további kutatások és adatgyüjtés fontosságát ezen a területen. Ezek mellett azonban érdemes még néhány szempontot megvizsgálni: először is, amikor a kutatási eredmények különbségeit vizsgáljuk nagy jelentőséggel bírhat az, hogy melyik kutatás, melyik fogalmat használja, szűkebb vagy tágabb értelemben vizsgálják-e a jelenségeket, szétválasztják-e például a procedurális igazságosságot és a hatékonyságot. Egyes kutatások a fogalmakat részletesen konceptualizálták és operacionalizálták, de voltak olyanok, ahol ez kevésbé derült ki a szövegből. Kérdéses lehet az is, hogy a válaszadók, hogyan értelmezték a kérdéseket. Mivel komplex fogalmak közötti összefüggéseket vizsgálnak a kutatások, ez különös relevanciával bírhat. A rendőrségbe vetett bizalmat például nem elégséges egy-két kérdéssel megvizsgálni, ahogy teszi például az egyik legnagyobb 
adatgyüjtés, az International Crime Victim Survey. Ennek a felmérésnek természetesen nem a kapcsolat kutatása a fó célja, ezért is van az, hogy kevés kérdés koncentrál a rendőrségbe vetett bizalomra. Ugyanakkor létezik olyan kérdőív, amely a bizalom kérdését mélységében körbejárja (European Social Survey), ugyanakkor az az adatbázis nem tartalmaz adatokat az áldozattá válásról és a feljelentési hajlandóságról. Ismételten, az adott kérdőívnek nem is ez a célja. Ugyanakkor a két kérdöívtípust használva, kiváló kérdőívet lehetne összeállítani annak érdekében, hogy a két komplex fogalom közötti összefüggés vizsgálható legyen. Az ideális az volna, ha egy ilyen kérdőív összeállítása, standardizálása után több országban felvehetők lennének az adatok, akár rendszeresen is, annak érdekében, hogy longitudinális vizsgálatokra is lehetőség legyen.

A fogalmak értelmezésének problematikájára az is megoldást jelenthet - a fent javasolt célzott és részletes kérdőívek mellett -, ha a fennálló kapcsolat meglétét nem csupán kvantitatív, hanem kvalitatív módszerekkel is kutatjuk. Például fókuszcsoportos vagy egyéni interjúkon lehetőség nyílna arra, hogy a kérdezők és a válaszadók tisztázzák, hogy mit is értenek egy-egy fogalom alatt, lehetőség nyílna visszakérdezésre, pontosításra, amely a fogalmak komplexitása miatt ebben az esetben különösen fontos lenne.

A szigorúan vett módszertani kérdéseken túlmutatóan több további faktor is felmerül, amely az eredményeket befolyásolja. Az eredményekből például jól láthatóvá vált, hogy ahol a bủncselekménytípusokat megkülönböztették, összehasonlították vagy egyetlen típust vizsgáltak csak, az azonnal jelentôs különbségekhez vezetett. Továbbá az is kiderült egy-egy kutatásból, hogy a többségi és kisebbségi társadalom attitüdjei és döntési mechanizmusai is eltérhetnek, például bevándorlók esetében fontos faktor lehet a kitoloncolástól való félelem (Messing, Becerra, Ward-Lasher \& Androff, 2015). Ezek mellett pedig figyelembe kell venni, hogy minden esetben egyéni döntésről van szó, amelyet rengeteg további szempont és faktor befolyásolhat, például a büncselekmény súlyossága, az elkövető személye, kapcsolata az áldozattal, biztosítás megléte, az áldozat szándéka stb. Annak érdekében, hogy ezen aspektusokkal kapcsolatban tisztábban lássunk, szintén kvalitatív kutatásokra lenne szükség a témában, amelyek akár a kérdőívek pontosításához is vezethetnének. 


\section{Felhasznált irodalom}

Ann Slocum, L., Taylor, T. J., Brick, B. T. \& Esbensen, F.-A. (2010). Neighborhood Structural Characteristics, Individual-level Attitudes, and Youth' Crime Reoprting Intentions. Criminology, 48(4), 1063-1100. https://doi.org/10.1111/j.1745-9125.2010.00212.x

Bennett, R. R. \& Wiegand, R. B. (1994). Observations on Crime Reporting in a Developing Nation. Criminology, 32(1), 135-148. https://doi.org/10.1111/j.1745-9125.1994.tb01149.x

Block, R. (1974). Why notify the police: The victim's decision to notify the police of an assault. Criminology: An Interdisciplinary Journal, 11(4), 555-569. https://doi. org/10.1111/j.1745-9125.1974.tb00614.x

Boateng, F. D. (2018). Crime Reporting Behavior: Do Attitudes Toward the Police Matter? Journal of Interpersonal Violence, 33(18), 2891-2916. https://doi.org/10.1177/0886260516632356

Culotta, K. A. (2015). Why Victims Hate to Report: Factors Affecting Victim Reporting in Hate Crime Cases in Chicago. Kriminologija \& Socijalna Integracija, 13(2), 15-27.

Davis, R. C. \& Hendricks, N. J. (2007). Immigrants and Law Enforcement: A Comparison of Native Born and Foreign-Born Americans' Opinions of the Police. International Review of Victimology, 14(1), 81-94. https://doi.org/10.1177/026975800701400105

Elntib, S., Nass, Z. S., Ioannou, M., Ryan, S. \& Christiansen, P. (2018). Is the Public Willing to Help the Nigerian Police During the Boko Haram Crisis? A Look at Moderating Factors. Journal of Police and Criminal Psychology, 33(1), 55-62. https://doi.org/10.1007/s11896-017-9234-0

Fishman, G. (1979). Patterns of Victimisation and Notification. The British Journal of Criminology, 19(2), 146-157. https://doi.org/10.1093/oxfordjournals.bjc.a046979

Goudriaan, H., Lynch, J. P. \& Nieuwbeerta, P. (2004). Reporting to the police in western nations: A theoretical analysis of the effects of social context. Justice Quarterly, 21(4), 933-969. https://doi.org/10.1080/07418820400096041

Goudriaan, H., Wittebrood, K. \& Nieuwbeerta, P. (2006). Neighbourhood Characteristics and Reporting Crime. The British Journal of Criminology, 46(4), 719-742. https://doi.org/10.1093/ bjc/azi096

Griffiths, C. E. (2018). The disjuncture between confidence and cooperation: Police contact amongst Polish migrants and established residents. European Journal of Criminology, 15(2), 197-216. https://doi.org/10.1177/1477370817712962

Hardin, R. (2006). Trust. Polity Press. Hickman, L. J., \& Simpson, S. S. (2003). Fair Treatment or Preferred Outcome? The Impact of Police Behavior on Victim Reports of Domestic Violence Incidents. Law and Society Review, 37(3), 607-634. https://doi.org/10.1111/1540-5893.3703005

Jackson, J., Brunton-Smith, I., Bradford, B., Oliveira, T. R., Pósch, K. \& Sturgis, P. (2020). Police Legitimacy and the Norm to Cooperate: Using a Mixed Effects Location-Scale Model to Estimate the Strength of Social Norms at a Small Spatial Scale. Journal of Quantitative Criminology, 37(7), 547-572. https://doi.org/10.1007/s10940-020-09467-5

Kääriäinen, J. \& Sirén, R. (2011). Trust in the police, generalized trust and reporting crime. European Journal of Criminology, 8(1), 65-81. https://doi.org/10.1177/1477370810376562 
Karakus, O. (2017). Instrumental and Normative Pathways to Legitimacy and Public Cooperation with the Police in Turkey: Considering Perceived Neighborhood Characteristics and Local Government Performance. Justice Quarterly, 34(1), 25-54. https://doi.org/10.1080/07 418825.2015.1095346

Khondaker, M. I., Wu, Y. \& Lambert, E. G. (2017). Bangladeshi immigrants' willingness to report crime in New York City. Policing and Society, 27(2), 188-204. https://doi.org/10.1080/ 10439463.2015.1040795

Kochel, T. R., Parks, R. \& Mastrofski, S. D. (2013). Examining police effectiveness as a precursor to legitimacy and cooperation with police. Justice Quarterly, 30(5), 895-925. https:// doi.org/10.1080/07418825.2011.633544

Kruger, D. J., Crichlow, V. J., McGarrell, E., Hollis, M., Jefferson, B. M., Reischl, T. M., \& Zimmerman, M. A. (2016). Perceptions of procedural justice mediate the relationship between local violent crime density and crime reporting intentions. Journal of Community Psychology, 44(6), 807-812. https://doi.org/10.1002/jcop.21797

Kwak, H., Dierenfeldt, R. \& McNeeley, S. (2019). The code of the street and cooperation with the police: Do codes of violence, procedural injustice, and police ineffectiveness discourage reporting violent victimization to the police? Journal of Criminal Justice, 60, 25-34. https:// doi.org/10.1016/j.jcrimjus.2018.11.001

Lee, Y. H. \& Cho, S. (2020a). Assessing a multidimensional model of police legitimacy in South Korea with latent class analysis. Journal of Crime and Justice, 1-22. https://doi.org/10.1 080/0735648X.2020.1773897

Lee, Y. H. \& Cho, S. (2020b). The Significance of Instrumental Pathways to Legitimacy and Public Support for Policing in South Korea: Is the Role of Procedural Fairness Too Small? Crime, Law and Social Change, 73(5), 575-603. https://doi.org/10.1007/s10611-019-09876-Z

Li, F., Sun, I. Y., Wu, Y. \& Liu, S. (2020). The mediating roles of law legitimacy and police legitimacy in predicting cooperation with police in China. Australian \& New Zealand Journal of Criminology, 000486582096564. https://doi.org/10.1177/0004865820965641

Messing, J. T., Becerra, D., Ward-Lasher, A. \& Androff, D. K. (2015). Latinas' perceptions of law enforcement: Fear of deportation, crime reporting, and trust in the system. Affilia, 30(3), 328-340. https://doi.org/10.1177/0886109915576520

Murphy, K. \& Barkworth, J. (2014). Victim willingness to report crime to police: Does procedural justice or outcome matter most? Victims \& offenders, 9(2), 178-204. https://doi.org/10 $.1080 / 15564886.2013 .872744$

Murphy, K. \& Cherney, A. (2011). Fostering cooperation with the police: How do ethnic minorities in Australia respond to procedural justice-based policing? Australian \& New Zealand Journal of Criminology, 44(2), 235-257. https://doi.org/10.1177/0004865811405260

Murphy, K., Cherney, A. \& Teston, M. (2019). Promoting Muslims'Willingness to Report Terror Threats to Police: Testing Competing Theories of Procedural Justice. Justice Quarterly, 36(4), 594-619. https://doi.org/10.1080/07418825.2018.1437210 
Murphy, K., Madon, N. S. \& Cherney, A. (2017). Promoting Muslims' cooperation with police in counter-terrorism: The interaction between procedural justice, police legitimacy and law legitimacy. Policing: An International Journal, 40(3), 544-559. https://oi.org/10.1108/ PIJPSM-05-2016-0069

Murphy, K., Madon, N. S. \& Cherney, A. (2020). Reporting threats of terrorism: Stigmatisation, procedural justice and policing Muslims in Australia. Policing and Society, 30(4), 361-377. https://doi.org/10.1080/10439463.2018.1551393

Murphy, K. \& Mazerolle, L. (2018). Policing immigrants: Using a randomized control trial of procedural justice policing to promote trust and cooperation. Australian \& New Zealand Journal of Criminology, 51(1), 3-22. https://doi.org/10.1177/0004865816673691

Özaşçılar, M., Narli, N. \& Öztürk, O. (2019). Crime Reporting Behavior Among Syrian Immigrants in Istanbul. Crime \& Delinquency, 65(14), 1997-2018. https://doi. org/10.1177/0011128718807157

Pósch, K., Jackson, J., Bradford, B. \& Macqueen, S. (2020). “Truly free consent”? Clarifying the nature of police legitimacy using causal mediation analysis. Journal of Experimental Criminology. https://doi.org/10.1007/s11292-020-09426-X

Rengifo, A. F., Slocum, L. A. \& Chillar, V. (2019). From Impressions to Intentions: Direct and Indirect Effects of Police Contact on Willingness to Report Crimes to Law Enforcement. Journal of Research in Crime and Delinquency, 56(3), 412-450. https://doi.org/10.1177/0022427818817338

Sargeant, E., Murphy, K. \& Cherney, A. (2014). Ethnicity, trust and cooperation with police: Testing the dominance of the process-based model. European Journal of Criminology, 11(4), 500-524. https://doi.org/10.1177/1477370813511386

Semukhina, O. (2014). Unreported crimes, public dissatisfaction of police, and observed police misconduct in the Volgograd region, Russia: A research note. International Journal of Comparative and Applied Criminal Justice, 38(4), 305-325. https://doi.org/10.1080/019240 36.2013 .872690

Skogan, W. G. (1976). Citizen Reporting of Crime - Some National Panel Data. Criminology, 13(4), 535-549. https://doi.org/10.1111/j.1745-9125.1976.tb00685

Skogan W. G. (1984). Reporting Crimes to the Police: The Status of World Research. Journal of Research in Crime and Delinquency, 21(2), 113-137. https://doi.org/10.1177/002242788 4021002003

Slocum, L. A. (2018). The Effect of Prior Police Contact on Victimization Reporting: Results from the Police-Public Contact and National Crime Victimization Surveys. Journal of Quantitative Criminology, 34(2), 535-589. https://doi.org/10.1007/s10940-017-9345-x

Sulkowski, M. L. (2011). An investigation of students' willingness to report threats of violence in campus communities. Psychology of Violence, 1(1), 53-65. https://doi.org/10.1037/a0021592

Sun, I. Y., Li, L., Wu, Y. \& Hu, R. (2018). Police Legitimacy and Citizen Cooperation in China: Testing an Alternative Model. Asian Journal of Criminology, 13(4), 275-291. https://doi. org/10.1007/s11417-018-9270-4 
Sunshine, J. \& Tyler, T. R. (2003). The Role of Procedural Justice and Legitimacy in Shaping Public Support for Policing. Law. Society Review, 37(3), 513-548. https://doi.org/10.1111/15405893.3703002

Tankebe, J. (2019). Cooperation With the Police Against Corruption: Exploring the Roles of Legitimacy, Deterrence and Collective Action Theories. The British Journal of Criminology, 59(6), 1390-1410. https://doi.org/10.1093/bjc/azz030

Tankebe, J., Reisig, M. D. \& Wang, X. (2016). A multidimensional model of police legitimacy: A cross-cultural assessment. Law and Human Behavior, 40(1), 11-22. https://doi.org/10.1037/ lhb0000153

Tsushima, M. \& Hamai, K. (2015). Public Cooperation With the Police in Japan: Testing the Legitimacy Model. Journal of Contemporary Criminal Justice, 31(2), 212-228. https://doi. org/10.1177/1043986214568836

Tyler, T. R. (2001). Public trust and confidence in legal authorities: What do majority and minority group members want from the law and legal institutions? Behavioral Sciences \& the Law, 19(2), 215-235. https://doi.org/10.1002/bsl.438

Tyler, T. R., \& Fagan, J. (2008). Legitimacy and cooperation: Why do people help the police fight crime in their communities. Ohio St. J. Crim. L., 6, 231-245.

Tyler, T. R., Schulhofer, S. \& Huq, A. Z. (2010). Legitimacy and Deterrence Effects in Counterterrorism Policing: A Study of Muslim Americans. Law \& Society Review, 44(2), 365-401.

Van Damme, A. \& Pauwels, L. (2016). Why are young adults willing to cooperate with the police and comply with traffic laws? Examining the role of attitudes toward the police and law, perceived deterrence and personal morality. International Journal of Law, Crime and Justice, 46, 103-116. https://doi.org/10.1016/j.ijlcj.2016.04.002

Wiedlitzka, S., Mazerolle, L., Fay-Ramirez, S. \& Miles-Johnson, T. (2018). Perceptions of Police Legitimacy and Citizen Decisions to Report Hate Crime Incidents in Australia. International Journal for Crime, Justice and Social Democracy, 7(2), 91-106. https://doi.org/10.5204/ ijcjsd.v7i2.489

\section{A cikk APA szabály szerinti hivatkozása}

Füstös M. (2022). A feljelentési hajlandóság és a rendőrségbe vetett bizalom összefüggései. Szisztematikus szakirodalmi áttekintés a Web of Science alapján. Belügyi Szemle, 70(1), 149-168. https://doi.org/10.38146/BSZ.2022.1.9 